\title{
Glycolytic and chitinolytic activities of Phlebotomus papatasi (Diptera: Psychodidae) from diverse ecological habitats
}

\author{
Raymond L. Jacobson, Liora Studentsky and Yosef Schlein
}

Department of Parasitology, The Hebrew University - Hadassah Medical School, P.O. Box 12272, Jerusalem, 91120, Israel

Key words: Phlebotomus papatasi, glycosidases, chitinases, oasis, arid

\begin{abstract}
The sand fly Phlebotomus papatasi Scopoli, 1786, the vector of Leishmania major Yakimoff et Schokhor, 1914, is found in desert areas where sugars are scarce but also in habitats that abound in sugar sources. The sand flies require sugar meals from plant sources for their energy requirements and to hydrolyze these complex sugars, they need a repertoire of glycosidases. We presumed that there are differences in the levels of glycosidase activities in flies from such habitats and also assumed that they may be instrumental in modulating the flies' susceptibility to L. major infections. Phlebotomus papatasi originating from diverse ecological habitats ranging from an oasis to desert sites were colonized. They were analyzed for weight changes and glycosidase activities before and after feeding on $1 \mathrm{M}$ sucrose solution. Oasis flies were smaller than desert flies but took larger sugar meals. Homogenates of these flies hydrolyzed 16 synthetic and 2 natural glycoside substrates to varying degrees. The arid-region flies tended to produce more glycosidase activity than those originating in sugar-rich environments, especially sucrase, $\alpha$ - and $\beta$ glucosidase, $\alpha$-fucosidase, $\alpha$-mannosidase, and $\alpha$ - and $\beta$ - $\mathrm{N}$-acetylgalactosaminidase. However, chitinolytic enzyme activities and particularly the $\beta-\mathrm{N}$-acetylhexosaminidase activity of oasis flies were higher than other flies tested. In comparing the desert flies, there were also significant differences in glycolytic enzyme activities between the spring-line (flowering season) of flies and the autumn-line (end of dry season) flies. A range of saccharide inhibitors was tested to demonstrate the specificity of the enzymes.
\end{abstract}

The energy requirements of both male and female sand flies are provided by staple sugar meals. Several different sources of sugar meals for both Phlebotomus and Lutzomyia species of sand flies have been described (Killick-Kendrick and Killick-Kendrick 1987, Molyneux et al. 1991). Specifically, these meals are obtained directly by feeding on plant tissue or nectar (Schlein and Warburg 1986, Schlein and Jacobson 1994, Cameron et al. 1995, Schlein and Müller 1995, Petts et al. 1997, Müller and Schlein 2004). Schlein and Warburg (1986) also reported that sand flies feed on honeydews excreted onto plants by aphids and coccids and this has been corroborated for other phlebotomine species (Moore et al. 1987, MacVicker et al. 1990, Wallbanks et al. 1991).

Sand flies are nocturnal and very small and based on field observation it was only possible to speculate that they feed on plant tissues (Ashford 1974). Therefore, most reports are based on limited local observations made by trapping flies where the plant either has been used as an attractant or is the dominant plant species. The reported sugar sources include diverse species such as coffee bushes (Coffea arabica) in Colombia (Alexander and Usma 1994), banana plantations (Musa sapientium) in India (Dinesh and Dhiman 1991), the fruit of the soapberry tree (Balanites aegyptiaca), the Shittim wood tree (Acacia seyal) and Combretum kordofanum in the Sudan, (Hamilton and El Naiem 2000).

Sugar-poor plant tissues are the basic diet of Phlebotomus papatasi Scopoli, 1786, the vector of Leishmania major Yakimoff et Schokhor, 1914, in arid areas (Schlein and Jacobson 1999). For example, the sugar content measured in Atriplex halimus leaves, a widespread chenopod in the arid site, was as low as $0.15 \%$, although it could rise to $0.5 \%$ when stressed without water (Schlein and Jacobson 2002, Martinez et al. 2004). The sugar concentration in nectar from Capparis spinosa, a common plant in Israel, ranges from $26.2 \%$ to $35.8 \%$ (Eisikowitch et al. 1986), while in aphid or coccid honeydews it is often higher (Byrne et al. 2003). Plant tissue may also contain starch granules, which are photosynthesis storage-products (Hopkins 1995) and have been reported in the midgut of $P$. papatasi (Schlein and Jacobson 2000); while various other polysaccharides have been found in some sand fly diet sources (Cameron et al. 1995).

The oligosaccharides encountered by the sand flies are possibly as diverse as the plant meals on which they feed. The main carbohydrates in aphid honeydews, a known sugar source for $P$. papatasi and $P$. ariasi Tonnoir, 1921 (Schlein and Warburg 1986, KillickKendrick and Killick-Kendrick 1987) are fructose, glucose and sucrose, but are dependent on the host plant (Byrne et al. 2003). Other saccharides found in sand fly sugar meals include maltose, maltotriose, trehalose, turanose, raffinose, and melibiose (Cameron et al. 1995).

Digestive glycosidase activity from $P$. papatasi, the vector of $L$. major, has been assayed using high performance liquid chromatography (Samie et al. 1990). This glycosidase activity of $P$. papatasi has been shown to include specifically $\alpha$-amylase and $\alpha$-glucosidase (Jacobson and Schlein 2001). Alpha-glucosidase activ- 
ity has been reported from both the midguts of Lutzomyia longipalpis Lutz et Neiva, 1912, the vector of $L$. chagasi Cunha et Chagas, 1937 (Gontijo et al. 1998) and $P$. langeroni Nitzulescu, 1930, the vector of $L$. infantum Nicolle, 1908, in which the enzyme activity increased following both sugar and blood meals (Dillon and El Kordy 1997). Alpha-amylase has been described from L. longipalpis, and following a blood meal it decreased in the salivary glands of the females (Charlab et al. 1999, Ribeiro et al. 2000). These sand flies also have glycosidases capable of hydrolyzing synthetic N-acteyl$\beta$-D-glucosaminide, $\mathrm{N}$-acteyl- $\beta$-D-galactosaminide and $\alpha$-L-fucopyranoside (Gontijo et al. 1996).

In this study, different colonies of $P$. papatasi from diverse origins were examined for a wide variety of glycosidase activities before and after sucrose meals. The specificity of the enzyme/substrate reaction was tested using appropriate carbohydrate inhibitors. The aim was to see whether there are differences between desert and oasis flies that may pertain to differences in their susceptibility to infection with L. major (Schlein and Jacobson 2001).

\section{MATERIALS AND METHODS}

Insects. Four colonies of the phlebotomine sand fly $P$. papatasi were maintained under identical conditions at a temperature of $26 \pm 1{ }^{\circ} \mathrm{C}$ and $80 \%$ R.H. The four colonies derived from progenitor flies caught in the following places in Israel: Neot Hakikar (352 m below sea level), a salt marsh oasis with lush vegetation in the southern Jordan Valley, where 10-12\% of the reservoir host Psammomys obesus Cretzschmar, 1828, is infected with L. major (Wasserberg et al. 2003, Müller and Schlein 2004); Kfar Adumim (350 m above sea level), $15 \mathrm{~km}$ east of Jerusalem, where L. major is absent, but P. papatasi are frequently found in houses (Schnur et al. 2004) and Gilgal ( $253 \mathrm{~m}$ below sea level), an arid area $30 \mathrm{~km}$ north of Jericho in the Jordan Valley, which is endemic for L. major and up to $90 \%$ of $P$. obesus are infected (Schlein et al. 1982, Schlein and Jacobson 2001). Two separate colonies were started from Gilgal, one from flies trapped at the beginning of the season (spring, mean annual rainfall is approximately $80 \mathrm{~mm}$ ), when there are islands of green vegetation, and the other from flies at the end of the season (dry summer - autumn) when the vegetation is sparse. A separate line of flies derived from Kfar Adumim females that were starved for 5 days until approximately $50 \%$ died, the survivors were then blood-fed and allowed to lay eggs. These sand flies were specifically bred to reproduce the conditions similar to those in arid areas and are more susceptible to infection with L. major than the founders (Schlein and Jacobson 2002). All colonies had been established within 24 months before the experiments were conducted, which is equivalent to $12-16$ generations.

Experimental flies were collected unfed $48 \mathrm{hr}$ after emergence, anaesthetized with $\mathrm{CO}_{2}$, weighed in batches of 10-15 flies on a fine balance (Mettler Toledo AB104-S, Switzerland) and stored at $-70^{\circ} \mathrm{C}$ until assayed. To test whether the glycosyl hydrolases found in unfed flies changed in response to a sugar meal, series of flies were fed on $1 \mathrm{M}$ sucrose solution for $48 \mathrm{hr}$ immediately after emergence and processed as above. Protein concentrations in the preparations were measured by the method of Bradford (1976), using a standard of bovine serum albumin.

Enzyme assays. Sand flies were suspended in the appropriate freshly made buffer (Table 1 ) at a dilution of $10 \mu 1 /$ fly. The flies were disrupted and homogenized on ice with fifty strokes of the pestle of a siliconized mini glass tissue homogenizer (Jencons Scientific Ltd, Leighton Buzzard, UK), centrifuged at $12,000 \mathrm{~g}$ for $10 \mathrm{~min}$ at $4^{\circ} \mathrm{C}$ and the supernatant removed for assaying. Preliminary studies performed on dissected whole guts, to ensure the enzymes were present, indicated a loss of glycolytic activity during the lengthy dissection process. We therefore measured enzyme activity in whole-fly homogenates to obtain maximal activity. Hence, the activities

Table 1. Experimental conditions used for measuring glycosylhydrolases of sand fly homogenates against various substrates.

\begin{tabular}{|c|c|c|c|c|}
\hline Substrates* & Enzyme EC No. & Buffer** & Stock concentration & Optimal pH \\
\hline$\alpha$-D-glucopyranoside & 3.2 .1 .20 & $\mathrm{CP}$ & $60 \mathrm{mM}$ & 6.6 \\
\hline$\beta$-D-glucopyranoside & 3.2 .1 .21 & $\mathrm{CP}$ & $60 \mathrm{mM}$ & 6.6 \\
\hline$\alpha$-D-galactopyranoside & 3.2.1.22. & $\mathrm{CP}$ & $60 \mathrm{mM}$ & 6.6 \\
\hline$\beta$-D-galactopyranoside & 3.2 .1 .23 & $\mathrm{CP}$ & $60 \mathrm{mM}$ & 6.6 \\
\hline NAc- $\alpha$-glucosaminide & 3.2 .1 .50 & $\mathrm{CP}$ & $6 \mathrm{mM}$ & 4.0 \\
\hline NAc- $\beta$-glucosaminide & 3.2 .1 .52 & $\mathrm{CP}$ & $6 \mathrm{mM}$ & 6.6 \\
\hline NAc- $\alpha$-galactosaminide & 3.2 .1 .49 & $\mathrm{CP}$ & $6 \mathrm{mM}$ & 6.6 \\
\hline NAc- $\beta$-galactosaminide & 3.2 .1 .53 & $\mathrm{CP}$ & $6 \mathrm{mM}$ & 6.6 \\
\hline$\alpha$-D-mannopyranoside & 3.2.1.24 & $\mathrm{CP}$ & $60 \mathrm{mM}$ & 5.7 \\
\hline$\beta$-D-mannopyranoside & 3.2 .1 .25 & $\mathrm{CP}$ & $6 \mathrm{mM}$ & 5.7 \\
\hline$\alpha$-L-fucoside & 3.2 .1 .51 & $\mathrm{CP}$ & $6 \mathrm{mM}$ & 5.7 \\
\hline$\beta$-D-fucoside & 3.2 .1 .38 & $\mathrm{CP}$ & $6 \mathrm{mM}$ & 5.7 \\
\hline$\alpha$-D-maltopentaoside & 3.2 .1 .1 & Hepes & $2.2 \mathrm{mM}$ & 7.4 \\
\hline$\beta$-diacetyl chitobioside & 3.2 .1 .14 & $\mathrm{AP}$ & $22 \mathrm{mM}$ & 5.0 \\
\hline$\alpha$-arabinopyranoside & 3.2 .1 .88 & AP & $60 \mathrm{mM}$ & 5.7 \\
\hline$\beta$-xylopyranoside & 3.2.1.37 & AP & $60 \mathrm{mM}$ & 5.7 \\
\hline MUF $\beta-D-N, N$ '-diacetylchitobioside & 3.2 .1 .14 & $\mathrm{CP}$ & $500 \mu \mathrm{M}$ & 4.83 \\
\hline MUF $\beta-D-N, N$ 'N"' triacetylchitobioside & 3.2.1.- & $\mathrm{CP}$ & $250 \mu \mathrm{M}$ & 4.83 \\
\hline Sucrose (natural) & 3.2 .1 .26 & SP & $50 \mathrm{mM}$ & 6.0 \\
\hline Maltose (natural) & 3.2.1.- & SP & $50 \mathrm{mM}$ & 6.0 \\
\hline
\end{tabular}

*All 4-Nitrophenyl unless otherwise stated, MUF - 4-methylumbelliferyl; **buffer 50 mM: CP - Citrate Phosphate; AP - Acetate Phosphate; $\mathrm{SP}$ - Sodium Phosphate; Hepes $110 \mathrm{mM}$. 
of all enzymes are presented as standardized hydrolytic activity, (Units/fly, where Units $=\mu \mathrm{mol}$ hydrolyzed substrate $/ \mathrm{min}$; see Martínez del Río et al. 1995, Jacobson and Schlein 2001, for an explanation of the use of this standardization). To ensure that these procedures resulted in complete extraction of membrane-bound enzymes, preliminary studies were conducted to compare enzyme activities in uncentrifuged homogenates, and supernatant fractions. Activities obtained were equivalent, showing that extraction of all enzymes was complete and no activity resided in the insoluble precipitates. All assays were performed with $10-15$ pooled flies, and repeated six times or more over a 12-month period.

Substrates were dissolved, with the aid of a stirring bar, in the appropriate buffer warmed to $37^{\circ} \mathrm{C}$ (Table 1). The assays were performed as previously described for $\alpha$-amylase and $\alpha$ glucosidase (Jacobson and Schlein 2001). All other 4nitrophenol assays were conducted with $10 \mu \mathrm{l}$ of fly homogenate in $90 \mu \mathrm{l}$ buffer and $20 \mu \mathrm{l}$ of substrate stock (Table 1). The 4-methylumbelliferyl (MUF) assays were conducted with 10 $\mu 1$ of fly homogenate in either $86 \mu 1$ buffer and $24 \mu 1$ stock for chitinase or $62 \mu \mathrm{l}$ buffer and $48 \mu \mathrm{l}$ substrate stock for chitotriosidase. The reaction mixtures were incubated for $2 \mathrm{hr}$ at $37^{\circ} \mathrm{C}$ and terminated with equal quantities of $0.45 \mathrm{M}$ $\mathrm{NaOH} /$ glycine $(\mathrm{pH}$ 10.2). The reactions were centrifuged at $12,000 \mathrm{~g}$ for $5 \mathrm{~min}$ and the absorbance of the clear supernatants were measured at $405 \mathrm{~nm}$ in a plate reader (Bio-Tek Instruments, Winooski, USA) against a substrate blank.

Disaccharidase activity was determined according to methods described by Martínez del Río et al. (1995) with some modification. Sucrase and maltase assays were performed with $2 \mu 1$ of homogenate suspended in $38 \mu 150 \mathrm{mM}$ sodium phosphate buffer $\mathrm{pH} 6.0$ and $10 \mu \mathrm{l} 50 \mathrm{mM}$ sucrose solution or 50 $\mathrm{mM}$ maltose solution was added and incubated for $90 \mathrm{~min}$ at $37^{\circ} \mathrm{C}$. Following incubation, $150 \mu \mathrm{l}$ fresh Trinder's reagent (Lee et al. 1998) were added and incubated for a further 30 min at $37^{\circ} \mathrm{C}$. The reactions were measured at $495 \mathrm{~nm}$ in the plate reader against a substrate blank. To test whether fructose was hydrolyzed from the disaccharides, a modification of the tryptamine $\mathrm{HCl}$ method (Taylor 1995) was used in parallel with the disaccharidase assays. Briefly, after incubation with substrates, $10 \mu \mathrm{l}$ of $25 \mathrm{mM}$ tryptamine in $0.1 \mathrm{M} \mathrm{HCl}$ and 150 $\mu 110 \mathrm{M} \mathrm{HCl}$ was added to the reaction, incubated at $60^{\circ} \mathrm{C}$ for 15 minutes and for a further $45 \mathrm{~min}$ at room temperature. These reactions were measured against a substrate/chromogen blank at $495 \mathrm{~nm}$ as above. The reactions using 4-methylumbelliferyl (MUF) substrates were measured in a fluorescent plate reader (Fluoroscan Ascent FL, Labsystems, Finland), under the following conditions $\lambda_{\mathrm{ex}}=360 \mathrm{~nm} ; \lambda_{\mathrm{em}}=455 \mathrm{~nm}$ against a substrate blank.

Optimum $\mathrm{pH}$ was pre-determined for all assays. Absorbance was converted to enzyme units using standard curves of either p-nitrophenyl or MUF.

One enzyme unit of activity (U) is the amount of enzyme required to hydrolyze $1 \mu \mathrm{M}$ of substrate per minute under the conditions of the assay. For maltase and sucrase activity, one unit of enzyme activity is defined as the amount of enzyme that releases $1 \mu \mathrm{M}$ glucose from the relevant substrate per minute at $37^{\circ} \mathrm{C}$.

Enzyme inhibition assays. The carbohydrates chosen as possible inhibitors of the sand fly glycosidases were selected with reference to those entered into the Comprehensive Enzyme Information System database (BRENDA) which provides detailed information on all the known enzymes from many different taxa (Schomburg et al. 2004). The following saccharides were used at 10,50 and $100 \mathrm{mM}$ final concentrations: monosaccharides: glucose, galactose, mannose, fructose; disaccharides: sucrose, maltose, lactose, cellbiose; Nacetylated sugars: $\mathrm{N}$-acetylglucosamine, N-acetylgalactosamine; sugar alcohols: inositol, erythritol; methyl glycoside: methyl- $\alpha$-mannopyranoside. The pseudotrisaccharide allosamidin was used at $1,2,3.3,5.0,7.5$ and $10 \mu \mathrm{M}$ final concentrations. Each saccharide was either incubated with the fly homogenate at $37^{\circ} \mathrm{C}$ for $1 \mathrm{hr}$ before the addition of the substrate or added at the same time. It was found that there was no difference in inhibition of enzyme activity if pre-incubation was carried out. The results in Table 5 are the maximum inhibition or activation obtained regardless of saccharide concentration.

Statistical analysis. The Student $t$-test, ANOVA, Wilcoxon signed rank test (WSR) and Dunnett's Multiple Comparison (DMC) test were performed using GraphPad Prism version 4.00 for Windows, GraphPad Software, San Diego California, USA, to compare the results from the various colonies. $P<0.05$ was considered significant (Zar 1999).

\section{RESULTS}

Weight of sand flies

The mean weight (m.w.) of unfed female sand flies was always greater than that of males from the same colony; female m.w. $=295 \mu \mathrm{g}(95 \%$ CI $0.277-0.312)$; male m.w. $223 \mu \mathrm{g}(95 \%$ CI $0.213-0.233)$. Flies of the Jordan Valley autumn line were significantly heavier than flies from the other colonies (DMC: females and males: $P<0.01$; Fig. 1). Generally, when sand flies were allowed access to $30 \%$ sucrose for $48 \mathrm{hr}$ after emergence, the mean increase in weight for females was 113 $\mu \mathrm{g} \mathrm{(95 \%} \mathrm{CI} \mathrm{107-118)} \mathrm{and} 50 \mu \mathrm{g}$ (95\% CI 41-59) for males. The exception was the Jordan Valley autumnline flies that took relatively very small sugar meals: females increased by $55.8 \mu \mathrm{g} \quad(95 \%$ CI $30.7-82.9$; DMC: $P=0.04)$ and males by $18.8 \mu \mathrm{g}(95 \%$ CI $11.5-$ 26.3; DMC: $P=0.002$ ) (Fig. 1).

There was no statistical difference between the total protein of the homogenates of female flies from the four series, $(P>0.16$, range 13.6-20.7 $\mu \mathrm{g})$, but the total protein of the males ranged from as low as $3.85 \mu \mathrm{g}$ (Neot Hakikar line) to a maximum of $12.6 \mu \mathrm{g}$ (Jordan Valley spring line). There is a strong positive correlation between protein levels and the weight of each series of sand flies (Pearson's correlation $\mathrm{r}=0.6985$ (95\% CI $0.3101-0.8871)$.

\section{Enzyme assays}

Sand fly homogenates of either sex from the four colonies hydrolyzed most of the substrates tested under the conditions of the assays (Table 1). The only exceptions, on which there was no measurable activity, were the substrates 4-nitrophenyl-N-acetyl- $\alpha$-glucosaminide and 4-nitrophenyl-D-N, N'- $\beta$-diacetyl chitobioside. 


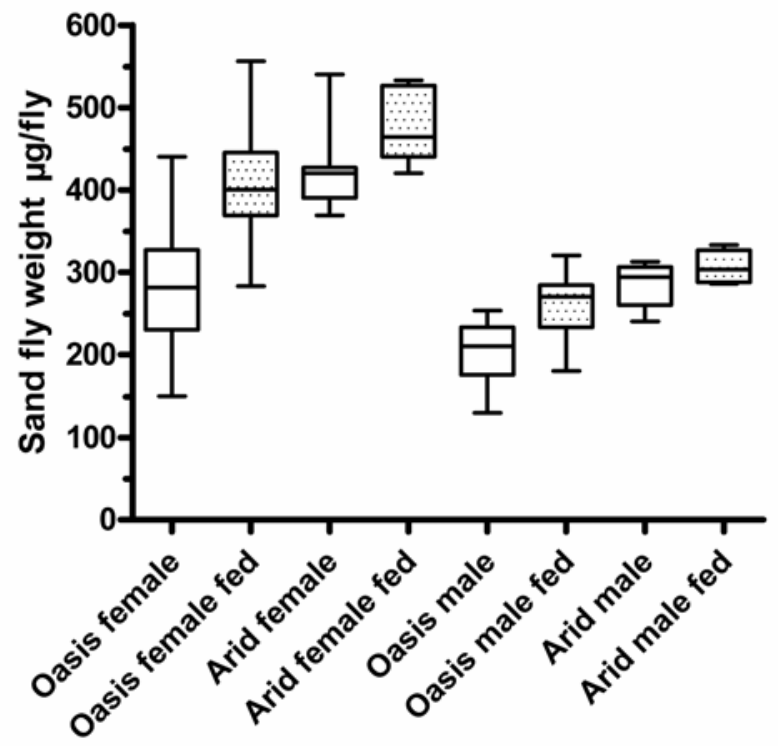

Fig. 1. Comparison of the weight of female and male Phlebotomus papatasi from an oasis (Neot Hakikar) and a hyperarid area (Jordan Valley autumn line) before (open box) and after (filled box) feeding on $1 \mathrm{M}$ sucrose. Box and whiskers plot. $(n \geq 25)$.

The sand fly homogenates contained substantial amounts of enzyme that were able to hydrolyze the specific substrates for sucrase, maltase, $\alpha$ - and $\beta$-glucosidase, $\alpha$-amylase, and $\beta-\mathrm{N}$-acetylhexosaminidase. Enzymatic activities were lower $(<1 \mathrm{U} / \mathrm{fly})$ on the substrates specific for $\alpha$ - and $\beta$-galactosidase, $\alpha$ - and $\beta$-N-acetylgalactosaminidase, $\alpha$ - and $\beta$-mannosidase, $\alpha$ - and $\beta$ fucosidase, chitinase and chitotriosidase. Discernible, but low levels of enzymes ( $\leq 0.1 \mathrm{U} /$ fly) hydrolyzed the substrate specific for $\alpha$-arabinase and occasionally there were some inconsistent and inconclusive very low levels of $\beta$-xylosidase.
The enzyme preparations of sand flies originating from the arid region in the dry season (Jordan Valley autumn line) consistently hydrolyzed more substrate than other flies except for chitinolytic enzymes. In either sex 8/14 enzymatic activities were significantly higher in arid region flies than in oasis flies (Tables 2, 3). Particularly noticeable was the low sucrase activity in unfed oasis flies compared to other series, while the amounts of maltase were commensurate. Also oasis females generated more $\beta$ - $\mathrm{N}$-acetylhexosaminidase than any other colony (WSR: $P=0.0313$ ), and oasis males produced more $\alpha-\mathrm{N}$-acetyl-galactosaminidase than the other colonies (WSR: $P=0.02$ ). Both the arid region colonies, spring and autumn fly lines, had significantly lower levels of two of the chitinolytic enzymes, while the progeny of the starved Kfar Adumim line had higher levels of chitinase and chitotriosidase than other colony flies (WSR: $P=0.0156$ ) (Table 2). The females from Jordan Valley spring line had significantly elevated levels of chitotriosidase activity (DMC: $P=0.04$ ).

In sucrose-fed flies there was an increase of activity in four enzymes and a decrease in three enzymes (Table 4). Increased activity was found for sucrase and maltase for all the lines, except for females of the starved fly line; for $\beta$-N-acetylhexosaminidase, except for the females from the oasis line and starved flies line and for $\beta$-fucosidase except for the oasis-line females. Reduced activity was found for $\alpha$-glucosidase except for the Jordan Valley spring males; for $\beta$-mannosidase and for $\alpha$ $\mathrm{N}$-acetylgalactosaminidase except for the starved-line females. In the other enzymes response to sugar feeding was varied and not dependent on fly line or sex. For example, in desert females (Jordan Valley autumn line) the $\beta$-glucosidase activity decreased by $30.5 \%$, while in the desert males this enzyme activity increased by $14.7 \%$ (Table 4 ).

Table 2. Phlebotomus papatasi female glycosidases (U/fly/min). Mean $\pm \mathrm{SE}$ ( $\mathrm{n} \geq 6$ groups; 10-15 flies/group).

\begin{tabular}{lcccc}
\hline Enzyme & $\begin{array}{l}\text { Neot Hakikar } \\
\text { (oasis) }\end{array}$ & $\begin{array}{l}\text { Jordan Valley } \\
\text { spring (wet) }\end{array}$ & $\begin{array}{l}\text { Kfar Adumim } \\
\text { starved (arid) }\end{array}$ & $\begin{array}{l}\text { Jordan Valley } \\
\text { autumn (arid) }\end{array}$ \\
\hline$\alpha$-glucosidase & $11.5 \pm 1.5$ & $14.9 \pm 0.5$ & $15.0 \pm 2.0$ & $21.6 \pm 2.0^{\mathrm{abc}}$ \\
$\beta$-glucosidase & $0.84 \pm 0.2$ & $0.72 \pm 0.05$ & $0.64 \pm 0.09$ & $1.06 \pm 0.07^{\mathrm{abc}}$ \\
$\alpha$-galactosidase & $0.24 \pm 0.09$ & $0.12 \pm 0.02$ & $0.19 \pm 0.06^{\mathrm{b}}$ & $0.37 \pm 0.16^{\mathrm{bc}}$ \\
$\beta$-galactosidase & $0.42 \pm 0.13$ & $0.29 \pm 0.01$ & $0.29 \pm 0.06$ & $0.34 \pm 0.04$ \\
$\alpha$-amylase & $3.41 \pm 0.32$ & $4.5 \pm 0.22$ & $2.8 \pm 0.5^{\mathrm{b}}$ & $3.97 \pm 0.4$ \\
$\alpha$-fucosidase & $0.1 \pm 0.15$ & $0.50 \pm 0.14^{\mathrm{a}}$ & $0.08 \pm 0.02^{\mathrm{b}}$ & $0.34 \pm 0.1^{\mathrm{abc}}$ \\
$\beta$-fucosidase & $0.24 \pm 0.02$ & $0.24 \pm 0.02$ & $0.22 \pm 0.02$ & $0.28 \pm 0.02$ \\
$\alpha$-mannosidase & $0.07 \pm 0.02$ & $0.39 \pm 0.2$ & $0.11 \pm 0.03$ & $0.76 \pm 0.26^{\mathrm{ac}}$ \\
$\beta$-mannosidase & $0.19 \pm 0.05$ & $0.25 \pm 0.03$ & $0.15 \pm 0.01 \mathrm{~b}$ & $0.2 \pm 0.03$ \\
$\alpha$-arabinase & $0.03 \pm 0.01$ & $0.07 \pm 0.01^{\mathrm{a}}$ & $0.05 \pm 0.02^{\mathrm{a}}$ & $0.05 \pm 0.01^{\mathrm{a}}$ \\
NAc- $\alpha$-galactosaminidase & $0.39 \pm 0.06$ & $0.22 \pm 0.05$ & $0.15 \pm 0.02^{\mathrm{a}}$ & $0.34 \pm 0.09$ \\
NAc- $\beta$-galactosaminidase & $0.15 \pm 0.05$ & $0.63 \pm 0.25^{\mathrm{a}}$ & $0.06 \pm 0.04^{\mathrm{b}}$ & $0.66 \pm 0.24^{\mathrm{abc}}$ \\
Sucrase & $38.9 \pm 3.0$ & $53.5 \pm 3.4^{\mathrm{a}}$ & $68.6 \pm 6.4^{\mathrm{a}}$ & $50.1 \pm 4.6^{\mathrm{ac}}$ \\
Maltase & $55.2 \pm 4.0$ & $56.0 \pm 3.3$ & $60.8 \pm 6.8$ & $52.5 \pm 3.0$ \\
NAc- $\beta$-hexosaminidase & $3.3 \pm 0.37$ & $0.19 \pm 0.03^{\mathrm{a}}$ & $1.19 \pm 0.39^{\mathrm{ab}}$ & $0.27 \pm 0.04^{\mathrm{abc}}$ \\
Chitinase & $0.86 \pm 0.2$ & $0.48 \pm 0.3$ & $0.95 \pm 0.05$ & $0.14 \pm 0.06^{\mathrm{ac}}$ \\
Chitotriosidase & $0.11 \pm 0.02$ & $0.47 \pm 0.14^{\mathrm{a}}$ & $0.29 \pm 0.01^{\mathrm{ab}}$ & $0.06 \pm 0.03^{\mathrm{abc}}$ \\
\hline
\end{tabular}

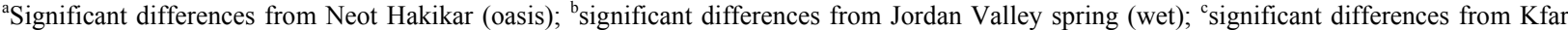
Adumim starved (arid). 
Table 3. Phlebotomus papatasi male glycosidases (U/fly/min). Mean $\pm \mathrm{SE}$ ( $\mathrm{n} \geq 6$ groups; $10-15$ flies/group).

\begin{tabular}{lcccc}
\hline Enzyme & $\begin{array}{l}\text { Neot Hakikar } \\
\text { (oasis) }\end{array}$ & $\begin{array}{l}\text { Jordan Valley } \\
\text { spring (wet) }\end{array}$ & $\begin{array}{l}\text { Kfar Adumim } \\
\text { starved (arid) }\end{array}$ & $\begin{array}{c}\text { Jordan Valley } \\
\text { autumn (arid) }\end{array}$ \\
\hline$\alpha$-glucosidase & $8.9 \pm 1.4$ & $11.6 \pm 1.5$ & $15.8 \pm 2.9^{\mathrm{a}}$ & $11.32 \pm 1.3^{\mathrm{a}}$ \\
$\beta$-glucosidase & $0.47 \pm 0.1$ & $0.44 \pm 0.6$ & $0.59 \pm 0.06$ & $0.39 \pm 0.09^{\mathrm{c}}$ \\
$\alpha$-galactosidase & $0.15 \pm 0.07$ & $0.05 \pm 0.01^{\mathrm{a}}$ & $0.08 \pm 0.01$ & $0.3 \pm 0.11^{\mathrm{abc}}$ \\
$\beta$-galactosidase & $0.28 \pm 0.07$ & $0.18 \pm 0.002$ & $0.3 \pm 0.05^{\mathrm{b}}$ & $0.16 \pm 0.01^{\mathrm{c}}$ \\
$\alpha$-amylase & $1.4 \pm 0.11$ & $3.21 \pm 0.1$ & $1.7 \pm 0.16^{\mathrm{b}}$ & $2.5 \pm 0.25^{\mathrm{abc}}$ \\
$\alpha$-fucosidase & $0.03 \pm 0.01$ & $0.16 \pm 0.04^{\mathrm{a}}$ & $0.07 \pm 0.02^{\mathrm{a}}$ & $0.21 \pm 0.02^{\mathrm{ac}}$ \\
$\beta$-fucosidase & $0.09 \pm 0.02$ & $0.11 \pm 0.005$ & $0.18 \pm 0.01^{\mathrm{ab}}$ & $0.14 \pm 0.02$ \\
$\alpha$-mannosidase & $0.04 \pm 0.01$ & $0.12 \pm 0.04$ & $0.03 \pm 0.02^{\mathrm{b}}$ & $0.11 \pm 0.05$ \\
$\beta$-mannosidase & $0.12 \pm 0.02$ & $0.15 \pm 0.02$ & $0.11 \pm 0.02^{\mathrm{b}}$ & $0.14 \pm 0.005^{\mathrm{b}}$ \\
$\alpha$-arabinase & $0.04 \pm 0.02$ & $0.04 \pm 0.02$ & $0.024 \pm 0.007^{\mathrm{ab}}$ & $0.04 \pm 0.003^{\mathrm{abc}}$ \\
NAc- $\alpha$-galactosaminidase & $0.21 \pm 0.07$ & $0.15 \pm 0.04$ & $0.17 \pm 0.06 \mathrm{c}$ & $0.14 \pm 0.01^{\mathrm{ac}}$ \\
NAc- $\beta$-galactosaminidase & $0.08 \pm 0.03$ & $0.05 \pm 0.01$ & $0.01 \pm 0.007^{\mathrm{ab}}$ & $0.39 \pm 0.2^{\mathrm{abc}}$ \\
Sucrase & $34.5 \pm 5.8$ & $45.5 \pm 8.2$ & $32.4 \pm 6.4$ & $50.5 \pm 2.4^{\mathrm{ac}}$ \\
Maltase & $42.8 \pm 7.9$ & $40.8 \pm 8.6$ & $31.9 \pm 6.6$ & $51.4 \pm 1.5^{\mathrm{c}}$ \\
NAc- $\beta$-hexosaminidase & $0.44 \pm 0.2$ & $0.1 \pm 0.02^{\mathrm{a}}$ & $0.18 \pm 0.06^{\mathrm{a}}$ & $0.12 \pm 0.03^{\mathrm{a}}$ \\
\hline
\end{tabular}

${ }^{a}$ Significant differences from Neot Hakikar (oasis); ${ }^{b}$ significant differences from Jordan Valley spring (wet); ${ }^{c}$ significant differences from Kfar Adumim starved (arid).

Table 4. Increase or decrease in glycosidase activities by percentage in Phlebotomus papatasi after feeding on $1 \mathrm{M}$ sucrose solution.

\begin{tabular}{|c|c|c|c|c|c|c|c|c|}
\hline \multirow[t]{2}{*}{ Enzyme } & \multicolumn{2}{|c|}{$\begin{array}{l}\text { Neot Hakikar } \\
\text { (oasis) }\end{array}$} & \multicolumn{2}{|c|}{$\begin{array}{l}\text { Jordan Valley } \\
\text { spring (wet) }\end{array}$} & \multicolumn{2}{|c|}{$\begin{array}{l}\text { Kfar Adumim } \\
\text { starved (arid) }\end{array}$} & \multicolumn{2}{|c|}{$\begin{array}{l}\text { Jordan Valley } \\
\text { autumn (arid) }\end{array}$} \\
\hline & 우우 & $\hat{\partial} \partial$ & 우우 & $\hat{\partial} \sigma^{\lambda}$ & 우 & ठิ่ & 우 & $\hat{\partial} \hat{\sigma}$ \\
\hline$\alpha$-glucosidase & -17.2 & -17.4 & -10.0 & 10.0 & -46.1 & -45.3 & -27.6 & -4.1 \\
\hline$\beta$-glucosidase & -26.3 & 14.4 & -9.8 & -5.7 & 15.7 & -4.8 & -30.5 & 14.7 \\
\hline$\alpha$-galactosidase & -44.1 & -44.0 & 21.9 & 38.0 & -46.0 & -3.4 & -66.8 & -46.1 \\
\hline$\beta$-galactosidase & -31.4 & -46.5 & 4.6 & 6.7 & -0.7 & -28.6 & 25.4 & 34.6 \\
\hline$\alpha$-fucosidase & -52.9 & 38.7 & -34.7 & 37.9 & 6.7 & -15.9 & -45.9 & -55.9 \\
\hline$\beta$-fucosidase & -3.85 & 38.4 & 16.1 & 28.0 & 39.5 & 21.2 & 20.9 & 25.9 \\
\hline$\alpha$-mannosidase & 61.7 & 14.1 & -14.9 & 35.4 & -23.5 & -15.3 & -28.3 & 43.9 \\
\hline$\beta$-mannosidase & -21.2 & -11.4 & -14.5 & -40.7 & 11.6 & -0.38 & -6.9 & -23.2 \\
\hline$\alpha$-arabinase & 23.4 & 25.5 & -17.3 & -16.7 & 12.4 & 11.7 & 44.4 & 40.1 \\
\hline NAc- $\alpha$-galactosaminidase & -46.9 & -14.2 & -11.9 & -20.7 & 1.9 & -21.9 & -43.2 & -3.3 \\
\hline NAc- $\beta$-galactosaminidase & 0.8 & -10.0 & -76.7 & -45.7 & 44.3 & 64.3 & 30.2 & 22.2 \\
\hline Sucrase & 33.3 & 33.8 & 16.2 & 18.2 & -26.5 & -0.9 & 17.3 & 4.4 \\
\hline Maltase & 5.3 & 14.9 & 7.4 & 28.3 & -11.3 & 18.7 & 11.6 & 1.8 \\
\hline$\alpha$-amylase & -19.0 & -17.1 & 2.8 & -11.7 & 17.2 & -1.8 & -9.0 & 2.8 \\
\hline NAc- $\beta$-hexosaminidase & -72.2 & 28.2 & 71.0 & 71.3 & -88.5 & 73.0 & 68.1 & 82.9 \\
\hline
\end{tabular}

Negative values - decrease.

\section{Enzyme inhibition assays}

To test the specificity of the sand fly glycosidases, various saccharides were tested at three concentrations, 10,50 and $100 \mathrm{mM}$. The chitinase inhibitor allosamidin was used at six concentrations from 1 to $10 \mu \mathrm{M}$. Three types of reactions were observed: dose dependent, where the inhibition increased proportionally to the concentration of inhibitor; constant inhibition, where the maximum inhibition was obtained by the lowest concentration of inhibitor and remained constant regardless of increasing quantities of saccharide; enzyme activation, where in the presence of the carbohydrate, more substrate was hydrolyzed that in its absence. No inhibition was observed with cellobiose and only very low levels $(<15 \%)$ were caused by lactose, fructose and methyl- $\alpha$-D-mannopyranoside when tested with various enzyme/substrate combinations. Sucrose was moderately inhibitory of glucosidase reactions, while activat- ing the $\beta$-galactosidase hydrolysis of the $\beta$-D-galactopyranoside substrate.

Of the sugar alcohols tested, inositol activated both $\beta$-galactosidase and $\beta$-glucosidase, but was a poor inhibitor of $\alpha$-glucosidase. Erythritol was an effective inhibitor of glucosidase, $\beta$-N-acetylhexosaminidase, maltase and sucrase activity (Table 5).

$\mathrm{N}$-acetyl-glucosamine was a potent inhibitor of chitinase, $\beta$-N-acetylhexosaminidase, and $\beta-\mathrm{N}$-acetyl- galactosaminidase, and inhibited a constant $53 \%$ of chitotriosidase activity, but had virtually no effect on $\alpha-\mathrm{N}$ acetylgalactosaminidase. However, N-acetylgalactosamine was a lower level dose-dependent inhibitor of $\beta$ $\mathrm{N}$-acetylgalactosaminidase, but gave a constant $65-75 \%$ inhibition of $\alpha-\mathrm{N}$-acetylgalactosaminidase and $\beta-\mathrm{N}$ acetylhexosaminidase. Mannose was a potent inhibitor of $\alpha$-mannosidase activity $(67.8 \%)$, but only inhibited $20 \%$ of $\beta$-mannosidase activity. This monosaccharide 
Table 5. Inhibition of selected female sand fly glycosidases by appropriate saccharides.

\begin{tabular}{|c|c|c|c|c|c|}
\hline \multirow{2}{*}{$\begin{array}{l}\text { Nutritional } \\
\text { enzymes }\end{array}$} & \multicolumn{5}{|c|}{ Inhibition $(\%) *$} \\
\hline & Glucose & Galactose & Inositol & Sucrose & Erythritol \\
\hline$\alpha$-glucosidase & 64.0 & 12.8 & 20 & 50.8 & 87.4 \\
\hline$\beta$-glucosidase & 80.3 & ND & -33.9 & 36.4 & 73.2 \\
\hline$\alpha$-galactosidase & 0 & 83.8 & 0 & 0 & ND \\
\hline$\beta$-galactosidase & 30.0 & 63.5 & -22.9 & -39.2 & ND \\
\hline NAc- $\beta$-hexosaminidase & 27.4 & 38.7 & ND & 24.1 & 64.8 \\
\hline \multirow{2}{*}{$\begin{array}{l}\text { Chitinolytic } \\
\text { enzymes }\end{array}$} & \multicolumn{5}{|c|}{ Inhibition $(\%) *$} \\
\hline & Erythritol & NAcglucosamine & NAcgal & tosamine & Allosamidin** \\
\hline NAc- $\beta$-hexosaminidase & 64.8 & 76.2 & & & ND \\
\hline Chitinase & 18.1 & 78.0 & & & 18.1 \\
\hline Chitotriosidase & 35.3 & 53.0 & & & 35.3 \\
\hline
\end{tabular}

*Inhibiting saccharides were used at three concentrations, 10,50 , and $100 \mathrm{mM}$; **allosamidin (used at six concentrations between 1 and $10 \mu \mathrm{M}$ ); numbers are the maximum $\%$ inhibition or activation (negative values); ND - not done.

also inhibited $\beta-\mathrm{N}$-acetylhexosaminidase, but increased $\alpha$-galactosidase activity. Maltose inhibited $68.2 \%$ of the $\alpha$-amylase reaction. Saccharide inhibitory or activation concentrations were generally dose dependent, with 100 $\mathrm{mM}$ as the most effective. However, in the following combinations constant inhibition was observed, where $10 \mathrm{mM}$ was sufficient to give maximum inhibition: glucose/ $\beta$-galactosidase, $\mathrm{N}$-acetyl-glucosamine/chitotriosidase and $5 \mu \mathrm{M}$ allosamidin/chitotriosidase. Constant enzyme activation was observed with only these combinations: inositol/ $\beta$-glucosidase and inositol/ $\beta$-galactosidase.

\section{DISCUSSION}

Phlebotomus papatasi is widely spread in Europe, Africa and Asia, particularly between 20 and 45 degrees in the northern latitudes. It breeds as far west as Portugal, throughout the Mediterranean littoral, the Adriatic region, the Balkans, the Middle East, North Africa, Central Asia and the Indian sub-continent (Lewis 1982). Phlebotomus papatasi is the main proven vector of Leishmania major in the Old World, north of the Sahara where zoonotic cutaneous leishmaniasis is established in the reservoir hosts (Ashford and Bettini 1987). The vectorial competence of this sand fly for $L$. major has been well documented, since laboratory-reared flies have been widely used in experiments on vector-parasite interactions. However, the vector potential may be initially dissimilar as we have shown that there are considerable differences in the susceptibility to L. major between flies from diverse environmental habitats (Schlein and Jacobson, 2001, 2002). First generation progeny of $P$. papatasi caught in an oasis (Neot Hakikar) had lower infection rates, $24.8 \%(25 / 101)$, than progeny of flies from arid areas (Jordan Valley) $82.5 \%$ $(156 / 189)$, while the mean number of parasites was 10 times greater in the latter. This and our previously published evidence suggested that the sugar starvation tolerance of flies from sugar-poor arid areas was associated and presumably linked with high susceptibility to L. major (Schlein and Jacobson 2002). We therefore investigated the possibility that sand fly lines from habitats rich or poor in sources of sugars differ in the enzymatic activities that are involved in the digestion of sugar meals. We also assumed that the results may indicate some mechanism that can modulate the vector potential of $P$. papatasi (Jacobson et al. 2001).

There was a considerable divergence in the enzymatic activities of flies from the colony lines. The greatest difference was between the fly line from the sugarrich oasis and the colony of desert, dry-season flies (10/17 of female and 9/15 of male enzymatic activities; Tables 2,3). The latter also differed in $8 / 17$ female activities from Jordan Valley spring flies and 9/17 activities from the starvation-selected fly line. The parallel differences between males were smaller and included $4 / 15$ and 7/15 activities when desert-autumn flies were compared to desert-spring and to starved fly lines respectively. The enzymatic activities associated with the degradation of chitin were relatively low in desertautumn flies while those of other enzymes were relatively higher. We suggest that these differences should be attributed to differences in sugar diets that had been available to the originating fly groups of the sand fly colonies. This assumption conforms to the concept that adaptation of a taxonomic group of insects to a particular diet may alter the activities of enzymes (Applebaum 1985, Ferreira et al. 1998). Desert-autumn flies were heavier than oasis flies and some of their enzymatic activities were higher while others were relatively lower. Similar phenomena that were observed for laboratory-selected starvation-resistant Drosophila melanogaster (Harshman et al. 1999) support our assumption that desert sand flies in the dry season are naturally selected for survival during sugar shortages.

There is very little information on plant sources of $P$. papatasi sugar meals and there are no studies on their composition. The three possible sugar sources are phloem sap (mainly sucrose), floral nectar (mainly glucose, fructose and sucrose, Petanidou 2005) and hemipteran honeydews (complexes of saccharides including glucose, fructose, trehalulose, melezitose, sucrose isomers and polyols, Byrne et al. 2003). However, the levels of sugar-degrading enzymatic activities provide some clues for the identification of the sources. For ex- 
ample, the oasis flies had lower levels of enzymes that hydrolyze $\alpha$-D-glucose, the terminal sugar for most honeydew polysaccharides, and the hexose mannose, an oxidation product of the mannitol in phloem. The oasis females had $46.8 \%$ less $\alpha$-glucosidase, $22 \%$ less sucrase and $90 \%$ less $\alpha$-mannosidase than females from the arid desert (Table 2). These lower levels may indicate that the flies from the oasis, where sugar meal sources abound, expend less metabolic energy on producing unnecessary high levels of carbohydrases. In contrast, the flies from the sugar-poor desert regions, must extract their energy from every possible source, and therefore continue to maintain elevated levels of glycosidases. Sucrose and starch are the main photosynthesis products of plants and many species accumulate large amounts of starch grains in the chloroplast (Hopkins 1995). Chenopods, a major component of desert vegetation, accumulate mostly starch (Lunn and Hatch 1995) and we have previously reported starch granules in the midgut of sand flies that have been exposed to flowerless branches (Schlein and Jacobson 2000). Therefore the activity of amylase is apparently required for degrading the starch that is found in plant tissue and not in nectar and honeydew. It is interesting to note that many of the sugar degrading activities of desert-autumn flies were higher than that of their parallels in the other groups (Tables 2, 3) and it may be a characteristic of adaptation to sugar shortage.

A novel characteristic of the oasis flies was that they produced proportionally twice as much sucrase after a sugar meal than any other line, although the sugar-meal size was similar to flies from Jordan Valley spring and Kfar Adumim starved colonies. While there was an overall trend of increased production of six enzymes, and a decrease in seven, in no series was it universal, which may reflect the uneven quantities imbibed by the various groups over time (Table 4). It should be stressed that the quantities of all glycosyl hydrolases examined after the sucrose meal were different from the amounts from the unfed flies. We attribute these changes to the enzyme activities in the alimentary canal during digestion.

Most of the glycosidases described from these sand flies are for carbohydrates found in plants, though these may be linked as sugar polymers, mono- and disaccharides, such as arabinose, galactose, rhamnose (Hamilton and El Naiem 2000). Alpha-galactosidase is the enzyme known to cleave raffinose and stachyose, complex oligosaccharides that sequentially link galactose and glucose or fructose units and are found in many plants, especially in desiccation tolerant plants (Ghasempour et al. 1998). This enzyme was found in significant amounts in all the flies tested, especially in the arid Jordan Valley autumn line.

The glucosidases are difficult to characterize as individual enzymes in the sand flies. However, the $\mathrm{K}_{\mathrm{m}}$, and $\mathrm{pH}$ optima were different for sucrase, maltase and $\alpha$ - glucosidase: $\mathrm{K}_{\mathrm{m}}=10.61,3.38,95.11 \mathrm{mM} ; \mathrm{V}_{\max }=9.04$,

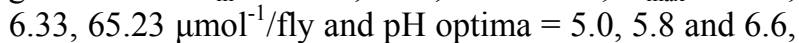
respectively. Similarly, regression analysis of the results of the fly groups with these three enzymes showed little or no correlation between them (unpublished data). Furthermore, when the sucrase and maltase assays were tested for the presence of free fructose, the sucrase assay was positive for both glucose and fructose signifying it probably acts as a $\beta$-fructofuranosidase, while the maltase was positive for only glucose. Surprisingly, the gut enzymes were able to catalyze $10 \mathrm{mM}$ fructose, indicating the presence of a separate $\beta$-fructosidase enzyme.

$\mathrm{N}$-acetylgalactosidases and $\beta$-N-acetylhexosaminidase $(=\beta$-N-acetylglucosaminidase) enzyme activities could be responsible for degradation of complex-type oligosaccharide chains containing LacdiNAc (GalNAc $\beta 1 \rightarrow$ 4GlcNAc $\beta 1-\mathrm{R}$ ) units (Do et al. 1997). Another possibility is that the $\beta$-N-acetylhexosaminidase enzyme, like lysozyme, act as microbiocidal proteins by attacking the cell wall of ingested bacteria. However, $\beta$ $\mathrm{N}$-acetylhexosaminidase may also be part of the chitinolytic enzyme system that has been reported for both $P$. papatasi and Lutzomyia longipalpis (RamalhoOrtigao et al. 2005), although these authors state that chitinase activity in the midgut is only expressed after a blood meal, while we have measured chitinolytic activity in whole body homogenates.

In our fly homogenates, all three chitinolytic activities, ( $\beta-\mathrm{N}$-acetylhexosaminidase, chitinase, chitotriosidase) were found without any induction by blood- or sugar-meals. Sand flies with high levels of chitinolytic activity may hydrolyze the peritrophic matrix (PM) before the promastigotes are able to establish themselves in the anterior alimentary canal, and therefore the parasites would be excreted with the remnants of the PM (Ramalho-Ortigao et al. 2005). The oasis flies, which were considered inferior vectors of L. major in the field, generate more of these enzymes than the arid flies, which are excellent vectors in nature. It is surmised that the female sand flies utilize these enzymes to break down the PM, but as male sand flies also generate these enzymes, there may be other functions of these glycosidases. Allosamidin, a potent inhibitor of chitinase, only inhibited the chitotriosidase activity to the same degree as achieved by $\mathrm{N}$-acetylglucosamine. This suggests that the sand flies have a cascade of chitinolytic enzymes, both exo- and endo-chitinases, but are only revealed when fluorogenic substrates are used (Schlein et al. 1991).

The sand flies in our colonies have a wide repertoire of glycosidases that are presumably capable of hydrolyzing the saccharides found in and on plants which are the natural sugar meals of these insects in nature (Jacobson et al. 2001). The degree of glycosidase activities tended to reflect the origin of the sand flies, where those from sugar-rich areas had less than those from arid areas, while chitinolytic enzymes were higher in those 
flies which originally had lower vector potential. The promastigotes that inhabit the sand fly alimentary canal can either aid or compete for the available nutrients, but appear to be unaffected by the sand flies' own glycosidases (Gontijo et al. 1996, Jacobson and Schlein 1997).
Acknowledgements. We wish to thank Dr. Shonei Sakuda for the generous gift of allosamidin. This work was supported by the Israel Science Foundation grant No. 559/04.

\section{REFERENCES}

AleXANDER B., USMA M.C. 1994: Potential sources of sugar for the phlebotomine sandfly Lutzomyia youngi (Diptera: Psychodidae) in a Colombian coffee plantation. Ann. Trop. Med. Parasitol. 88: 543-549.

APPleBAuM S.W. 1985: Biochemistry of digestion. In: G.A. Kerkut and L.I. Gilbert (Eds.), Comprehensive Insect Physiology, Biochemistry and Pharmacology. Vol. 4. Pergamon Press, New York, pp. 279-311.

ASHFORD R.W. 1974: Sandflies (Diptera: Phlebotomidae) from Ethiopia: taxonomic and biological notes. J. Med. Entomol. 11: 605-616.

ASHFORD R.W., BETTINI S. 1987: Ecology and epidemiology: Old World. In: W. Peters and R. Killick-Kendrick (Eds.), The Leishmaniasis in Biology and Medicine, Vol. 1. Academic Press, London, pp. 365-424.

BRADFORD M.M. 1976: A rapid and sensitive method for the quantitation of microgram quantities of protein utilizing the principle of protein-dye binding. Analyt. Biochem. 72: 248 254.

BYRnE D.N., HENDRIX D.L., Williams L.H. 2003: Presence of trehalulose and other oligosaccharides in hemipteran honeydew, particularly Aleyrodidae. Physiol. Entomol. 28: 144 149.

CAMERon M.M., Pessoa F.A., VAsconcelos A.W., WARd R.D. 1995: Sugar meal sources for the phlebotomine sandfly Lutzomyia longipalpis in Ceara State, Brazil. Med. Vet. Entomol. 9: 263-272.

Charlab R., Valenzuela J.G., Rowton E.D., Ribeiro J.M.C. 1999: Toward an understanding of the biochemical and pharmacological complexity of the saliva of a hematophagous sand fly Lutzomyia longipalpis. Proc. Natl. Acad. Sci. U.S.A. 96: $15155-15160$.

DILLON R.J., EL KORDY E. 1997: Carbohydrate digestion in sandflies: alpha-glucosidase activity in the midgut of Phlebotomus langeroni. Comp. Biochem. Physiol. B - Biochem. Mol. Biol. 116: $35-40$.

DINESH D.S., DHIMAN R.C. 1991: Plant sources of fructose to sandflies, particularly Phlebotomus argentipes in nature. J. Commun. Dis. 23: 160-161.

Do K-Y., Do S.I., CUMMINGS R.D. 1997: Differential expression of LacdiNAc sequences (GalNAcß1-4GlcNAc-R) in glycoproteins synthesized by Chinese hamster ovary and human 293 cells. Glycobiology 7: 183-194.

EISIKOWITCH D., IVRI Y., DAFNI A. 1986: Reward partitioning in Capparis spp. along ecological gradient. Oecologia 71: 4750.

FERrEIRA C., TORRES B.B., TERRA W.R. 1998: Substrate specificities of midgut beta-glycosidases from insects of different orders. Comp. Biochem. Physiol. B - Biochem. Mol. Biol. 119: 219-225.

GHASEMPOUR H.R., GAFF D.F., Williams R.P.W., GiANELlO R.D. 1998: Contents of sugars in leaves of drying desiccation tolerant flowering plants, particularly grasses. Plant Growth Regul. 24: 185-191.

Gontijo N.F., Almeida-Silva S., Costa F.F., Mares-GuiA M.L., Williams P., Melo M.N. 1998: Lutzomyia longipalpis: $\mathrm{pH}$ in the gut, digestive glycosidases, and some specula- tions upon Leishmania development. Exp. Parasitol. 90: 212219.

Gontijo N.F., Melo M.N., Riani E.B., Almeida-Silva S., MARES-GUIA M.L. 1996: Glycosidases in Leishmania and their importance for Leishmania in phlebotomine sandflies with special reference to purification and characterization of a sucrase. Exp. Parasitol. 83: 117-124.

Hamilton J.G.C., El NAiEM D.A. 2000: Sugars in the gut of the sandfly Phlebotomus orientalis from Dinder National Park, Eastern Sudan. Med. Vet. Entomol. 14: 64-70.

Harshman L.G., HofFMAnN A.A., ClarK, A.G. 1999: Selection for starvation resistance in Drosophila melanogaster: physiological correlates, enzyme activities and multiple stress responses. J. Evol. Biol. 12: 370-379.

HoPKINS W.G. 1995: Introduction to Plant Physiology. John Wiley and Sons, New York, 464 pp.

JACOBSON R.L., SCHLEIN Y. 1997: Cellulase activity of Leishmania major in the sandfly vector and in culture. J. Eukaryot. Microbiol. 44: 216-219.

JACOBSON R.L., SCHLEIN Y. 2001: Phlebotomus papatasi and Leishmania major parasites express alpha-amylase and alphaglucosidase Acta Trop. 78: 41-49.

JACOBSON R.L., SCHLEIN Y., EISENBERGER C.L. 2001: The biological function of sand fly and Leishmania glycosidases. Med. Microbiol. Immunol. 190: 51-55.

KILliCK-KendRICK R., KillicK-KendRICK M. 1987: Honeydew of aphids as a source of sugar for Phlebotomus ariasi. Med. Vet. Entomol. 1: 297-302.

LEE E.A., Weiss S.L., LAM M., TORRES R., DiAMOND J.A. 1998: Method for assaying intestinal brush-border sucrase in an intact intestinal preparation. Proc. Natl. Acad. Sci. U.S.A. 95: 2111-2116.

LEWIS D.J. 1982: A taxonomic review of the genus Phlebotomus (Diptera: Psychodidae). Bull. Brit. Mus. (Nat. Hist.), Entomol., 45: 121-209.

LUNN J.E., HATCH M.D. 1995: Primary partitioning and storage of photosynthate in sucrose and starch in leaves of $\mathrm{C}_{4}$ plants. Planta 197: 385-391.

MACVICKER J.A.K., MOORE J.S., MOLyneUX D.H., MAROLI M. 1990: Honeydew sugars in wild caught Italian phlebotomine sand flies (Diptera: Psychodidae) as detected by high performance liquid chromatography. Bull. Entomol. Res. 80: 339-344.

MARTineZ J.P., LutTS S., SChANCK A., BAJJi M., KinET J.M. 2004: Is osmotic adjustment required for water stress resistance in the Mediterranean shrub Atriplex halimus L? J. Plant Physiol. 161: 1041-1051.

MARTíneZ DEL RÍO C., BRUGGER K.E., Rios J.L., VERGARA M.E., WiTMER M. 1995: An experimental and comparative study of dietary modulation of intestinal enzymes in the European starling (Sturnus vulgaris). Physiol. Zool. 68: 490511.

MolyneuX D.H., Moore J., Maroli M. 1991: Sugars in sand flies. Parassitologia 33: 431-436.

MoOre J.S., Kelly T.B., Killick-KendRICK M., WALlbanKS K.R., MOLyneuX D.H., KILLICK-KENDRICK R. 1987: Honeydew sugars in wild caught Phlebotomus ariasi detected by 
high performance liquid chromatography (HPLC) and gas chromatography. Med. Vet. Entomol. 1: 427-434.

MÜLLER G., SCHLEIN Y. 2004: Nectar and honeydew feeding of Phlebotomus papatasi in a focus of Leishmania major in Neot Hakikar oasis. J. Vector Ecol. 29: 154-158.

PETANIDOU T. 2005: Sugars in Mediterranean floral nectars: An ecological and evolutionary approach. J. Chem. Ecol. 31: $1065-1088$.

PETTS S.L., TANG Y., WARD R.D. 1997: Nectar from a wax plant, Hoya sp., as a carbohydrate source for Lutzomyia longipalpis (Diptera: Psychodidae). Ann. Trop. Med. Parasitol. 91: 443446.

RIBEIRO J.M.C., ROWTON E.D., CHARLAB R. 2000: Salivary amylase activity of the phlebotomine sand fly, Lutzomyia longipalpis. Insect Biochem. Mol. Biol. 30: 271-277.

RAMALHO-ORTIGAO J.M., KAMHAWI S., JOSHI M.B., REYNOSO D., LAWYER P.G., DWYER D.M., SACKS D.L., VALENZUELA J.G. 2005: Characterization of a blood activated chitinolytic system in the midgut of the sand fly vectors Lutzomyia longipalpis and Phlebotomus papatasi. Insect Mol. Biol. 14: 703 712.

Samie M., Wallbanks K.R., MoORE J.S., MolyneuX D.H 1990: Glycosidase activity in the sandfly Phlebotomus papatasi. Comp. Biochem. Physiol. B - Biochem. Mol. Biol. 96: $577-579$.

SCHLEIN Y., JACOBSON R.L. 1994: Mortality of Leishmania major in Phlebotomus papatasi caused by plant-feeding of the sand flies. Am. J. Trop. Med. Hyg. 50: 20-27.

SCHLEIN Y., JACOBSON R.L. 1999: Sugar meals and longevity of the sandfly Phlebotomus papatasi in an arid focus of Leishmania major in the Jordan Valley. Med. Vet. Entomol. 13: $65-71$

SCHLEIN Y., JACOBSON R.L. 2000: Photosynthesis modulates the plant feeding of Phlebotomus papatasi (Diptera: Psychodidae). J. Med. Entomol. 37: 319-324.

SCHLEIN Y., JACOBSON R.L. 2001: Parasitic infection - Hunger tolerance and Leishmania in sandflies. Nature 414: 168.

SCHLEIN Y., JACOBSON R.L. 2002: Linkage between susceptibility of Phlebotomus papatasi to Leishmania major and hunger tolerance. Parasitology 125: 343-348.
SCHLEIN Y., JaCOBSON R.L., Shlomai J. 1991: Chitinase secreted by Leishmania functions in the sand fly vector. Proc. R. Soc. Lond., Ser. B - Biol. Sci., 245: 121-126.

SCHLEIN Y., MÜLLER G. 1995: Assessment of plant tissue feeding by sand flies (Diptera: Psychodidae) and mosquitoes (Diptera: Culicidae). J. Med. Entomol. 32: 882-887.

SCHLEIN Y., WARBURG A. 1986: Phytophagy and the feeding cycle of Phlebotomus papatasi (Diptera, Psychodidae) under experimental conditions. J. Med. Entomol. 23: 11-15.

SCHLEIN Y., WARBURG A., SCHNUR L.F., GUNDERS A.E. 1982: Leishmaniasis in the Jordan Valley II. Sand-flies and transmission in the central endemic area. Trans. R. Soc. Trop. Med. Hyg. 76: 582-586.

SCHNUR L.F., NASEREDDIN A., EISENBERGER C.L., JAFFe C.L., El FARI M., AZMi K., ANDERS G., Killick-Kendrick M., KILLICK-KENDRICK R., DEDET J.P., PRATLONG F., KANAAN M., GROSSMAN T., JACOBSON R.L., SCHONIAN G., WARBURG A. 2004: Multifarious characterization of Leishmania tropica from a Judean desert focus, exposing intraspecific diversity and incriminating Phlebotomus sergenti as its vector. Am. J. Trop. Med. Hyg. 70: 364-372.

Schomburg I., Chang A., Ebeling C., Gremse M., Heldt C., HuHN G., SCHOMBURG D. 2004: BRENDA, the enzyme database: updates and major new developments. Nucleic Acids Res. 32: D431-433.

TAYLOR K.A.C.C. 1995: A colorimetric fructose assay. Appl. Biochem. Biotechnol., Part A, Enzym. Eng. Biotechnol., 53: 215-227.

WALlBANKS K.R., MoORE J.S., BenNeT L.R., SOREN R., MOLYNEUX D.H., CARLin J.M., PereZ J.E. 1991: Aphid derived sugars in the sand fly Lutzomyia peruensis. Trop. Med. Parasitol. 42: 60-62.

WASSERBERG G., YAROM I., WARBURG A. 2003: Seasonal abundance patterns of the sandfly Phlebotomus papatasi in climatically distinct foci of cutaneous leishmaniasis in Israeli deserts. Med. Vet. Entomol. 17: 452-456.

ZAR J.H. 1999: Biostatistical Analysis. Fourth Edition. PrenticeHall, Englewood Cliffs, N.J., 663 pp. 